\title{
SUPERVISI AKADEMIK DALAM UPAYA PENINGKATAN MOTIVASI GURU MENYUSUN PERANGKAT PERSIAPAN PEMBELAJARAN
}

\author{
SAMIUDDIN \\ MTsN 3 Buton Tengah \\ E-mail : samiuddinsaga@gmail.com
}

\begin{abstract}
ABSTRAK
Penelitian ini bertujuan untuk mengetahui pengaruh penyelenggaraan supervisi akademik terhadap peningkatan motivasi guru dalam menyusun perangkat persiapan pembelajaran. Penelitian dirancang dalam 3 siklus, hal yang masing-masing siklus terdiri dari kegiatan perencanaan, pelaksanaan, pengamatan, refleksi dan revisi. Tindakan yang dilakukan ialah supervisi yang dilanjutkan dengan penagihan komitmen dan bimbingan. Adapun metode pengumpulan data yang digunakan ialah pengamatan dan wawancara. Sedang metode analisis data yang digunakan ialah metode diskriptif-comparatif. Hasil penelitian, secara kuantitatif menunjukkan adanya peningkatan motivasi guru dalam menyusun silabus dan RPP dari siklus 1, siklus 2 dan siklus 3. Pada siklus 2, demikian pula pada siklus 3. Berdasarkan data hasil tindakan dari siklus ke siklus, nampak ada perubahan atau perkembangan dari siklus 1 ke siklus 2 , dan dari siklus 2 ke siklus 3. Bila pada siklus 1, jumlah guru yang menyerahkan dokumen silabus adalah 4 orang atau 33,33\%, maka pada siklus 2 , jumlah guru yang sudah menyerahkan dokumen bertambah dengan 2 orang sehingga menjadi 6 orang guru atau 50\%. Selanjutnya pada siklus 3 jumlah guru yang menyerahan dokumen bertambah dengan 4 orang, sehingga jumlah seluruh guru yang sudah menyerahkan dokumen sampai dengan siklus 3, menjadi 10 orang atau 83,3\%.
\end{abstract}

Kata Kunci: supervisi akademik; motivasi; pembelajaran

\section{PENDAHULUAN}

Sebagaimana telah kita ketahui bersama bahwa tugas Guru Profesional, menurut Peraturan Pemerintah Republik Indonesia No. 74 tahun 2006, adalah menyusun perangkat pembelajaran, melaksanakan pembelajaran, melaksanakan penilaian pembelajaran, melaksanakan program perbaikan dan pengkayaan, melaksanakan analisis hasil penilaian dan melaksanakan tugas tambahan.Termasuk perangkat pembelajaran ialah kegiatan persiapan, yang meliputi kegiatan menyusun silabus, menyusun Rencana Pelaksanaan Pembelajaran (RPP), menyusun modul pembelajaran, dan menyusun media pembelajaran.

Walaupun tugas tersebut adalah tugas mulia seorang guru yang dijamin oleh undangundang, pada praktiknya masih banyak dijumpai keganjilan, yaitu belum semua guru melaksanakannya dengan baik. Guru belum melaksanakan penyusunan persiapan pembelajaran secara tertib, belum menyusun perangkat penilaian pembelajaran, guru belum melaksanakan analisis hasil penilaian, guru belum melaksanakan program perbaikan (remidi) dan pengkayaan, dst. Pada penelitian ini, penulis ingin memfokuskan pada penyusunan perangkat persiapan pembelajaran, yang berupa silabus dan Rencana Pelaksaanaan Pembelajaran (RPP).

Pendidikan adalah upaya yang secara sadar dirancang untuk membantu seseorang atau sekelompok orang dalam mengembangkan ilmu pengetahuan, pandangan hidup, sikap hidup, dan keterampilan hidup baik yang bersifat manual individual maupun sosial (Sagala, $2006: 1$ ). Upaya sadar untuk mengembangkan kepribadian dan kemampuan siswa tersebut dapat diselenggarakan dalam berbagai bentuk. Ada yang diselenggarakan secara sengaja, terencana, terarah dan sistematis seperti pada pendidikan formal, ada yang diselenggarakan secara sengaja, akan tetapi tidak terencana dan tidak sistematis seperti yang terjadi di lingkungan keluarga (pendidikan informal), dan ada yang diselenggarakan secara sengaja dan 
berencana, di luar lingkungan keluarga dan lembaga pendidikan formal, yaitu melalui pendidikan non formal.

Apapun bentuk penyelenggarannya, secara umum pendidikan bertujuan untuk membantu anak-anak atau peserta didik mencapai kedewasaannya masing-masing, sehingga mereka mampu berdiri di lingkungan masyarakatnya. Untuk masyarakat kita, sesuai dengan Undang-Undang Republik Indonesia Nomor 20 Tahun 2003 Tentang Sistem Pendidikan Nasional, pasal 3, pendidikan berfungsi dan bertujuan sebagai berikut:

Pendidikan nasional berfungsi mengembangkan kemampuan dan membentuk watak serta peradaban bangsa yang bermartabat dalam rangka mencerdaskan kehidupan bangsa, bertujuan untuk berkembangnya potensi peserta didik agar menjadi manusia yang beriman dan bertakwa kepada Tuhan Yang Maha Esa, berakhlak mulia, sehat, berilmu, cakap, kreatif, mandiri, dan menjadi warga negara yang demokratis serta bertanggung jawab.

Setidaknya ada 3 sebab yang sering muncul di permukaan sebagai alasan. Pertama, guru belum memiliki kecakapan atau keterampilan menyusun perangkat persiapan pembelajaran. Atau yang kedua, guru enggan untuk membuatnya. Kedua alasan inilah yang menarik untuk disimak, mengapa guru masih enggan untuk menyusun perangkat persiapan pembelajaran? Padahal, ia telah mendapat gaji rutin (bagi yang berstatus PNS) dalam jumlah yang relatif cukup, terlebih lagi, bagi guru yang sudah lolos sertifikasi, ia telah mendapat tunjangan sertifikasi guru dalam jumlah yang lumayan. Dengan nada seloroh, ada guru yang mengungkapkan alasan, yaitu "waktu yang digunakan untuk menyusun persiapan pembelajaran sering lebih lama daripada waktu penyajiannya".Bila demikian halnya, maka alasan yang ketiga, ialah bahwa guru tidak punya cukup waktu untuk membuatnya.

Ketiga sebab tersebut, menunjukkan bahwa wawasan guru terhadap pentingnya persiapan pembelajaran perlu mendapat perhatian. Padahal persiapan pembelajaran adalah kegiatan perencanaan, yaitu kegiatan awal dari sebuah manajemen kelas. Bagaimana kelas dikelola, sangat ditentukan pada kecermatan dalam perencanaannya. Menurut John McWell, keberhasilan suatu kegiatan, 70\%-nya ditentukan oleh kecermatan dalam tahap perencanaannya.

Beberapa solusi dapat ditempuh Kepala Sekolah untuk mengatasi masalah tersebut. Pertama, mengadakan workshop guru untuk menyusun perangkat persiapan pembelajaran, terutama untuk membimbing guru yang belum memiliki kecakapan untuk menyusun perangkat persiapan pembelajaran. Kedua, memberikan reward (penghargaan) kepada guru yang telah menyusun perangkat persiapan pembelajaran secara lengkap dalam satu semester. Ketiga, memberikan sanksi administrative kepada guru yang belum/tidak menyusun persiapan pembelajaran, setelah diberi batasan waktu yang cukup. Keempat, melakukan supervisi dan pendampingan kepada Guru dalam menyusun perangkat pembelajaran. Pada kesempatan ini penulis ingin mencoba menerapkan alternative yang keempat, yaitu meningkatkan kompetensi guru dengan menyelenggarakan supervisi akademik dan bimbingan/pendampingan. Dengan supervisi, diharapkan para guru dapat dipantau, dievaluasi dan ditindaklanjuti aktivitasnya dalam menyusun perangkat persiapan pembelajaran.

Rumusan masalah yang dapat penulis ajukan di sini ialah "Bagaimana Pengaruh Supervisi Akademik Terhadap Peningkatan Kompetensi Guru Dalam Menyusun Perangkat Persiapan Pembelajaran. Penelitian ini bertujuan untuk mengetahui besarnya pengaruh penyelenggaraan supervisi akademik terhadap peningkatan kompetensi guru dalam menyusun perangkat persiapan pembelajaran. Penelitian ini dikatakan berhasil bila terdapat peningkatan kompetensi guru dalam menyusun perangkat pembelajaran yang ditunjukkan dengan data bahwa minimal 70\% guru telah menyusun/menyerahkan dokumen persiapan pembelajaran.

Steers dan Porter dalam Nurul Yaqin (2004) yang berpendapat bahwa "The term motivation was originally derived from the latin word 'movere', which mean 'to move'. Motivasi adalah alasan, daya batin, dorongan. Dari pengertian ini dapat dikatakan bahwa 
motivasi adalah dorongan dari dalam diri seseorang untuk melakukan suatu tindakan. Masih dalam Nurul Yaqin (2004), Siagian berpendapat bahwa :

"Motivasi adalah daya pendorong yang mengakibatkan seseorang anggota organisasi mau dan rela untuk menggerakkan kemampuan dalam bentuk keahlian atau keterampilan, tenaga dan waktunya untuk menyelenggarakan berbagai kegiatan yang menjadi tanggungjawabnya dan memfungsikan kewajibannya, dalam rangka pencapaian tujuan dan berbagai organisasi yang telah ditentukan sebelumnya".

Secara konseptual, Supervisi akademik, ialah serangkaian kegiatan membantu guru mengembangkan kemampuannya mengelola proses pembelajaran demi pencapaian tujuan pembelajaran. Dengan demikian kegiatan supervisi adalah kegiatan yang positif dan mulia, yaitu membantu guru. Supervisi tidaklah berarti menilai kinerja guru, sehingga terkesan mencari atau menemukan kelemahan/kekurangan guru dalam melaksanakan pembelajaran, seperti kesan negatif yang selama ini tertanam dalam pandangan para guru. Hal ini sejalan dengan pendapat Sergiovanni, (dalam PPTK-BPSDM, 2013) yang menyatakan bahwa fungsi dan tujuan supervisi akademik ialah pengembangan profesionalisme, penumbuhan motivasi dan pengawasan kualitas.

\section{METODE PENELITIAN}

Penelitian ini dilaksanakan dengan menggunakan desain penelitian tindakan (aktion reserch) yang dirancang melalui tiga siklus, melalui prosedur: (1) perencanaan (planing), (2) pelaksanaan tindakan (actions), (3) pengamatan (observation), (4) refleksi (reflektions) dalam tiap-tiap siklus. Teknik analisis data yang digunakan dalam penelitian tindakan sekolah ini adalah sebagai berikut: 1)Teknik pengumpulan data yang digunakan dalam penelitian tindakan sekolah ini meliputi teknik tes dan non tes, namun demikian untuk memudahkan dalam pengolahan data, maka teknik yang digunakan hanya teknik yang berbentuk tes; 2)Jenis data yang akan digunakan adalah data kualitatif dan data kuantitatif. Data kualitatif adalah data yang diperoleh dari hasil observasi pada saat pembinaan berkelanjutaan berlangsung, sedangkan data kualitatif adalah nilai tugas dalam penelitian ini yaitu penyusunan rencana pelaksanaan pembelajaran; 3)Teknik dan pengambilan dan pengumpulan data pada penelitian tindakan sekolah ini dilakukan dengan cara berikut ini: (a)Metode pemberian tugas atau tes. Data prestasi diperoleh dengan memberikan tes sebagai alat evaluasi kepada guru. Tes atau tugas individu ini diberikan pada siklus I , siklus II dan III; (b)Metode angket: Metode ini digunakan peneliti untuk memperoleh informasi tentang masalah yang dihadapi guru dalam menyusun rencana pelaksanaan pembelajaran.; (c)Metode dokumentasi: Peneliti dalam penelitian ini merekam semua kegiatan penerapan supervisi edukatif berkelanjutan dengan menggunakan daftar pengamatan yang didokumentasikan.

\section{HASIL PENELITIAN DAN PEMBAHASAN}

Berdasarkan data hasil tindakan dari siklus ke siklus, nampak ada perubahan atau perkembangan dari siklus 1 ke siklus 2, dan dari siklus 2 ke siklus 3. Bila pada siklus 1, jumlah guru yang menyerahkan dokumen silabus adalah 4 orang atau 33,33\%, maka pada siklus 2 , jumlah guru yang sudah menyerahkan dokumen bertambah dengan 2 orang sehingga menjadi 6 orang guru atau 50\%. Selanjutnya pada siklus 3 jumlah guru yang menyerahan dokumen bertambah dengan 4 orang, sehingga jumlah seluruh guru yang sudah menyerahkan dokumen sampai dengan siklus 3, menjadi 10 orang atau 83,3\%. Dalam bentuk tabel, perkembangan jumlah guru yang menyerahkan dokumen silabus dan RPP, dapat disajikan sebagai berikut : 
Tabel 1 Perkembangan jumlah guru yang menyerahkan dokumen silabus dan RPP (dari siklus ke siklus)

\begin{tabular}{|c|c|c|c|c|c|c|c|c|}
\hline \multirow[t]{2}{*}{ No } & \multirow[t]{2}{*}{ Keterangan } & & \multicolumn{2}{|c|}{ Siklus 1} & \multicolumn{3}{|c|}{ Siklus 2} & Sik \\
\hline & & & Jumlah & $\%$ & Jumlah & $\%$ & Jumlah & $\%$ \\
\hline \multirow[t]{2}{*}{1} & Guru yang & sudah & 4 & 33,3 & 6 & 50 & 10 & 83,3 \\
\hline & menyerahkan & & & & & & & \\
\hline \multirow[t]{3}{*}{2} & Guru yang & belum & 8 & 66,7 & 6 & 50 & 2 & 16,7 \\
\hline & menyerahkan & & & & & & & \\
\hline & Jumlah & & 12 & 100 & 12 & 100 & 12 & 100 \\
\hline
\end{tabular}

Dalam bentuk diagram batang, perkembangan jumlah guru yang sudah menyerahkan dokumen silabus dan RPP dari siklus ke siklus dapat digambarkan sebagai berikut

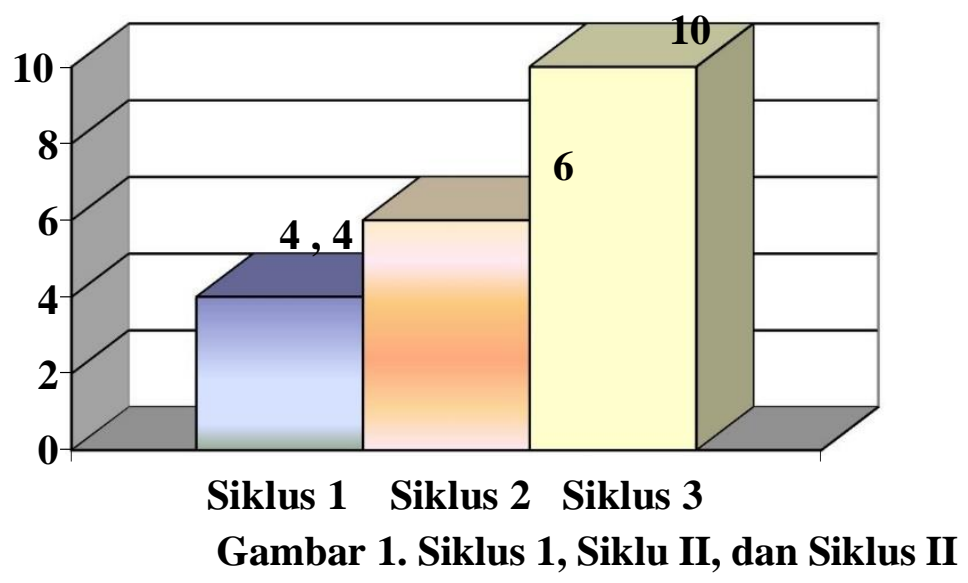

Data pada diagram batang tersebut menun jukkan adanya perubahan yang cukup signifikan, tentang motivasi guru dalam menyusun dokumen silabus dan RPP Kalau pada siklus 1, prosentase guru yang menyerahkan dokumen adalah sebesar 33,3\%, maka pada siklus 2 sudah menjadi 50\%, ada kenaikan sebesar 16,7\%. Selanjutnya pada siklus 3, prosentase jumlah guru yang menyerahkan dokumen menjadi83,3\%, naik sebesar 33,3\%.

Kenaikan yang cukup signifikan ini memberi pelajaran bagi kita, bahwa pengaruh supervisi akademik yang dilakukan dengan prinsip humanis dan kolaboratif, dengan menagih komitmen dan bimbingan, cukup efektif untuk meningkatkan kinerja guru. Hal ini dapat dipahami, bahwa di satu sisi, memang kecenderungan watak dasar manusia adalah suka melampauhi batas dan dhalim, sehingga diperlukan pengendalian dengan menagih komitmen. Sedang di sisi lain, manusia juga cenderung suka bersikap bodoh, sehingga ia memerlukan bimbingan teknis pelaksanaan tugasDengan demikian tugas Kepala Sekolah sebagai supervisor di sini adalah, pertama, membangkitkan komitmen guru, dan ketika komitmennya telah tumbuh, maka tugas kedua, adalah membimbingnya, yaitu menunjukkan cara, bagaimana melaksanakannya.

Perkembangan atau perubahan jumlah guru yang menyerahkan dokumen silabus dan RPP dari siklus ke siklus, menunjukkan perkembangan komitmen dan kompetensi guru dalam menyusun dokumen silabus dan RPP. Terutama adalah komitmen, yaitu kepedulian seseorang untuk melaksanakan tugas dengan sebaik-baiknya sesuai dengan tugas pokok dan fungsinya. Guru yang memiliki komitmen tinggi tentu memiliki motivasi dan tanggungjawab tinggi untuk melaksanakan tugas pokoknya. Dia akan mencurahkan banyak waktu dan tenaganya untuk menyelesaikan tugas pokoknya. Sebaliknya, guru yang tingkat komitmennya relatif rendah cenderung melalaikan tanggungjawab dan tugas pokoknya. Dia enggan mencurahkan waktu dan tenaganya untuk mengemban tugas pokoknya.Demikian pula tentang 
kompetensi, yaitu kemampuan teknis guru dalam melaksanakan tugas yang ditentukan oleh tingkat kedalaman pengetahuan yang dimiliki dan keterampilannya melaksanakan tugas, juga menentukan kualitas kinerja guru. Bagaimana mungkin seorang guru dapat melaksanakan tugasnya dengan baik bila tidak memiliki kompetensi memadai, walaupun komitmennya tinggi. Sehingga masalah kompetensi guru, tetap harus mendapat perhatian Kepala Sekolah dalam melaksanakan tugas supervisi.

Dengan demikian, upaya meningkatkan kinerja guru, berkisar pada masalah bagaimana meningkatkan komitmen dan kompetensi. Keduanya sangat ditentukan oleh suasana hati (keyakinan) dan perasaan (emosi) seseorang. Bila hati seseorang yakin adanya Tuhan yang satu (1), Tuhan Yang Maha Pengasih dan Penyayang, sedang emosinya dalam keadaan alfa (terkendali), dalam arti tidak marah, tidak malas, tidak takut, tidak khawatir, tidak malu dan tidak ragu-ragu, maka seseorang akan dapat melakukan apa saja. Hal ini sesuai dengan pendapat Ary Ginanjar Agustian, dalam ESQ POWER-nya, yang memformulasikan dalam rumus : $1 / 0=\sim$, Selanjutnya, masih menurut Ginanjar, bila hati seseorang dalam keadaan suci dan bersih, dalam arti tidak terblenggu oleh hawa nafsu, maka hati menjadi cerah dan bersinar. Ketila hati seseorang cerah dan bersinar, maka ia akan memiliki sikap terbuka, dalam arti bisa membedakan dengan jelas antara yang benar dan yang salah, dan siap menerima petunjuk tentang kebenaran, siap belajar apa saja. Dengan demikian dapat dikatakan bahwa tinggi rendahnya tingkat kinerja seseorang (guru) mencerminkan kombinasi antara tingkat keyakinannya kepada Tuhan dengan tingkat kemampuan pengendalian dirinya.

\section{KESIMPULAN}

Kesimpulan dari penelitian diatas antara lain: 1)Bahwa profesi guru adalah tugas mulia, yaitu mencerdaskan kehidupan bangsa, yang mestinya ditunaikan dengan niat mulia (komitmen) dan dengan keterampilan (kompetensi) memadai atau sesuai standar.. Komitmen yang tinggi lahir dari hati yang suci, bersih, bersinar terang atau tidak terbelenggu oleh hawa nafsu. Selanjutnya hati yang suci akan menggerakkan perasaan, pikiran dan tindakan fisik untuk menimba banyak pengetahuan, keterampilan memadai dan sikap yang benar. Jadi komitmen tinggi akan melahirkan kompetensi tinggi; 2)Adapun berbagai kasus tentang rendahnya kinerja guru, pada dasarnya terkait langsung dengan kualitas komitmen dan kompetensi tersebut. Sehingga sasaran pembinaannya juga pada masalah komitmen dan kompetensi. Bila komitmen ditentukan oleh keterbukaan hati, maka komitmen bisa dibangun dengan mencerahkan hatinya. Bila hati sudah bisa dicerahkan, maka semangat belajarnya akan tumbuh dan berkembang sejalan dengan pertumbuhan kompetensinya; 3)Karena kecenderungan sebagian besar manusia adalah dhalim dan bodoh, maka diperlukan upaya terus-menerus (konsisten, istiqomah) untuk membangun dan menagih komitmen melalui supervisi akademis (supervisi klinis) yang mengedepankan prinsip-prinsip humanis, kolaboratif, dll sehingga terbangun sinergy-building diantara Kepala Sekolah selaku supervisor dan guru; 4)Upaya meningkatkan kinerja guru, dalam hal ini menyusun perangkat persiapan pembelajaran (yaitu silabus dan RPP), melalui penagihan komitmen dan bimbingan, terbukti efektif. Hal ini ditunjukkan dengan adanya peningkatan jumlah guru yang menyerahkan dokumen silabus dan RPP dari siklus 1 hingga siklus 3 . Walaupun tetap harus diakui, masih ada juga guru, sebesar 16,7\%, yang hingga akhir siklus 3 belum juga menyerahkan. Hal ini bisa dimaklumi mengingat kesibukannya yang ekstra pada saat penelitian ini dilaksanakan. 


\section{DAFTAR PUSTAKA}

Departemen Pendidikan Nasional. (2002). Supervisi Pendidikan. Jakarta: Direktorat Pendidikan Lanjutan Menengah Pertama.

Depdiknas. (2005). Peraturan pemerintah Nomor 19 Tahun 2005 tentang Standar Nasional Pendidikan ,Jakarta

Mulyasa, E. (2007). Menjadi Guru professional. Menciptakan Pembelajaran Kreatif dan Menyenangkan. Bandung. PT. Remaja Rosdakarya.

Rosilawati, Titik. (2013). Peningkatan Motivasi Guru Dalam Penyusunan Perangkat Pembelajaran Melalui Supervisi Akademik.Brebes. (tidak dipublikasikan)

Sahertian Piet A. (2000). Konsep Dasar \& Teknik Supervisi Pendidikan. PT Rineka Cipta, Jakarta

Supandi. (1996). Administrasi dan Supervisi Pendidikan. Jakarta: Departemen Agama Universitas Terbuka. 